\title{
PENGEMBANGAN PERANGKAT PEMBELAJARAN BIOLOGI BERBASIS INKUIRI MATERI SISTEM EKSKRESI MANUSIA UNTUK MELATIH KETERAMPILAN BERPIKIR KRITIS DAN KERJASAMA SISWA SMA
}

\author{
Sri Istinafiatin Fadilah ${ }^{1)}$, Soeparman $\operatorname{Kardi}^{2)}$ Imam Supardi ${ }^{3)}$ \\ ${ }^{1)}$ Mahasiswa Program Studi Pendidikan Sains, Program Pascasarjana Universitas Negeri Surabaya \\ ${ }^{2), 3)}$ Dosen Pascasarjana Prodi Pendidikan Sains Univesrtitas Negeri Surabaya \\ E-mail: istinafiatian@gmail.com
}

\begin{abstract}
The aim of this research is to develop biology inquiry-based instructional materials, on the topic Human Excretion System to facilitate senior high school students to think critically and work cooperatively. The instructional materials consisted of the lesson plan, worksheet, learning material, and evaluation instruments. Before the try-outing, the instructional materials had been validated by expert and good categorized. The result showed that: 1) the developed instructional materials were feasible; 2) the lesson plan had been well implemented (98\%); 3) the highest students activities were discussion (27,56\%), writing hypotheses $(22,16 \%)$, formulating conclusion $(13,70 \%)$, and testing hypotheses using the data collection $(13,14 \%)$; 4$)$ student learning outcomes including the ability of the achievement of competence indicators completeness $88 \%$ and the think critically had reached $95,6 \%$ of mastery level in the indicator gives the argument $(92,6 \%)$ and take decisions and actions $(88,1 \%) ; 5)$ student motivation level based on the ARCS instrument were respectively: 4,48 for Attention, 4,44 for Relevance, 4,22 for Confidence, and 4,47 for Satisfaction. The percentage of student response to the instructional process was $80,77 \%, 84,62 \%$ to the teaching materials, $82,05 \%$ to the worksheets; and 6) $87,3 \%$ in collaboration work. Based on the above result showed that developed biology inquiry based instructional materials on the topic Human Excretion System were feasible to facilitate senior high school students to think critically and work cooperatively.
\end{abstract}

Keywords: Instructional Material, Inquiry, Critical Thinking Skill, Work Cooperatively

\begin{abstract}
Abstrak: Penelitian ini bertujuan untuk mengembangkan perangkat pembelajaran yang layak berdasarkan pendekatan berbasis inkuiri pada pokok bahasan sistem eksresi manusia dalam upaya untuk melatih keterampilan berpikir kritis dan kerjasama siswa SMA. Perangkat pembelajaran yang dikembangkan adalah Silabus, RPP, Materi Ajar, LKS, dan Instrumen Penilaian. Sebelum diujicobakan perangkat pembelajaran telah divalidasi oleh pakar dan hasilnya valid dan berkategori baik. Hasil penelitian menunjukkan bahwa: 1) perangkat pembelajaran yang telah dikembangkan secara keseluruhan layak digunakan; 2) keterlaksanaan RPP adalah 98\% terlaksana baik; 3) aktivitas siswa dalam proses pembelajaran yang tertinggi adalah berdiskusi dengan guru atau siswa lain, yaitu (27,56\%), menuliskan hipotesis (22,16\%), membuat kesimpulan (13,70\%), dan menguji hipotesis $(13,14 \%)$; 4) hasil belajar siswa yang meliputi ketuntasan indikator ketercapaian kompetensi $88,8 \%$ dan keterampilan berpikir kritis rata-rata $(95,6 \%)$ dengan persentase tertinggi pada indikator memberikan argumen $(96,2 \%)$ dan mengambil keputusan dan tindakan $(88,1 \%)$; 5) respon siswa siswa terhadap pembelajaran dapat dilihat dari nilai angket dengan menggunakan ARCS, yaitu untuk Attention (perhatian) $=4,48$, Relevance (relevansi) $=4,44$, Convidence $($ keyakinan $)=4,22$, dan Satisfacation (kepuasan) $=4,47$, Persentase respon untuk proses pembelajaran $80,77 \%$, materi ajar 84,62\%, dan LKS $82,05 \%$; 6) kemampuan kerjasama siswa tertinggi pada aspek menghargai anggota kelompok, yaitu 87,3\%. Berdasarkan hasil penelitian menunjukkan bahwa perangkat pembelajaran biologi berbasis inkuiri yang dikembangkan adalah layak dan dapat melatih keterampilan berpiki kritis dan kerjasama siswa SMA pada materi Sistem Ekskresi Manusia.
\end{abstract}

Kata Kunci: Perangkat Pembelajaran, Inkuiri, Keterampilan Berpikir Kritis, Kerjasama.

\section{PENDAhuluan}

Pengemasan pembelajaran dewasa ini sering didasarkan pada asumsi-asumsi yang tidak sejalan dengan hakekat belajar dan pembelajaran. Dunia belajar didekati dengan paradigma yang tidak mampu menggambarkan hakikat belajar dan pembelajaran secara komprehensif. Kemasan pembelajaran yang sering ditemukan menitikberatkan pada tuntutan kemampuan hafalan, memecahkan masalah lama, penanaman pola perilaku yang konfrontatif dan seragam dengan pola pengajaran bernuansa kompetitif dan persaingan. Proses pembelajaran biologi dewasa ini masih bersifat hafalan dan kurang mengembangkan proses berpikir. Pembelajaran biologi lebih banyak disuguhkan melalui pendekatan konsep atau produk yang hafalan. Pengajaran biologi lebih banyak bersifat 
informatif, hanya menekankan pada penguasaan fakta dan konsep (Puskur Balitbang Depdiknas, 2001). Kerangka pikir ini masih bertahan sampai sekarang karena terus dipelihara melalui ujian-ujian yang cenderung hanya menagih hafalan. Banyak lulusan sekolah menengah termasuk mahasiswa yang tahu banyak, tetapi tidak paham apa yang mereka ketahui. Motivasi belajar para siswa lebih pada mencari ijazah daripada mencari ilmu pengetahuan. Pelaksanaan pendidikan yang berorientasi pada kuantitas kelulusan ujian nasional daripada pengutamaan pada kualitas penguasaan ilmu yang diajarkan (BSNP, 2010:15).

Materi uji publik kurikulum 2013 mencantumkan, bahwa semua mata pelajaran yang diajarkan dengan pendekatan yang sama, yaitu pendekatan saintifik (ilmiah) melalui mengamati, menanya, mencoba/mengumpulkan informasi/mengumpulkan data, mengasosiasi/menalar, dan mengkomunikasikan. Kurniasih dan Berlin (2014:144) meyatakan bahwa kegiatan pembelajaran yang dilakukan melalui $5 \mathrm{M}$ ini dapat membangkitkan rasa ingin tahu, mendorong siswa untuk belajar aktif, mengembangkan kemampuan berpikir tinggi (higher order thinking skill), mendorong siswa berpartisipasi dalam diskusi kelompok, dan mendorong siswa untuk mengungkapkan ide atau argumentasinya. Hasan (2014) menyatakan pada makalahnya yang disampaikan dalam seminar nasional Inovasi Pendidikan Sains dalam menyongsong Kurikulum 2013, bahwa proses pembelajaran yang dilakukan berorientasi saintifik, siswa mencari tahu, setiap langkah pembelajaran menjadi kompetensi yang harus dilatih, penguatan dilakukan secara vertikal dan horizontal pada setiap mata pelajaran, dan setiap langkah pembelajaran dinilai. Permendiknas No. 65 tahun 2013 tentang Standar Proses Pendidikan Dasar dan Menengah juga telah mengisyaratkan tentang perlunya proses pembelajaran yang dipandu dengan kaidah-kaidah ilmiah/pendekatan saintifik. Penerapan pendekatan saintifik/ilmiah ini merupakan ciri khas dari keberadaan kurkulum 2013. Penguatan pendekatan saintifik perlu diterapkan pembelajaran berbasis penyingkapan/penelitian (discovery/inquiry learning).

Keadaan tersebut sejalan dengan penjelasan BSNP (2010:29) bahwa untuk tercapainya efektifitas dalam menjalankan fungsi penyalur dan pengembang ilmu pengetahuan, peran guru/dosen memiliki fungsi yang sangat sentral. Guru/dosen tidak hanya berfungsi sebagai sumber ilmu yang setiap saat menjadi acuan murid, tetapi ia juga harus berperan sebagai perangsang dalam pengembangan minat peserta didik dalam mencari ilmu pengetahuan secara mandiri. Ilmu pengetahuan didapat, selain hasil interaksi dengan guru/dosen, juga dari hasil penjelajahan peserta didik sendiri (personal discovery) dengan membaca buku, melakukan penelitian, mengikuti diskusi keilmuan, atau pun perenungan/refleksi. Kepiawaian guru/dosen dalam menumbuhkan minat peserta didik untuk menggali ilmu secara mandiri ini sangat penting disbanding transfer ilmu yang diperoleh murid dari guru/dosen secara langsung. Karena itu, bentuk-bentuk pendidikan partisipatif dengan menerapkan metode belajar aktif (active learning) dan belajar bersama (cooperative learning) sangat diperlukan.

Penjelasan tersebut memberikan gambaran bahwa pembelajaran yang dilakukan di kelas hendaknya mampu melibatkan siswa secara aktif, sehingga pembelajaran yang dilakukan lebih mengena pada diri siswa, mudah diingat dan tahan lama tersimpan dalam memori otaknya.

Biologi merupakan bagian dari sains yang mampu mengembangkan keterampilan proses ilmiah. Pembelajaran biologi, didalamnya memberikan berbagai pengalaman menarik bagi siswa sehingga dapat memahami proses sains. Proses ini meliputi berbagai keterampilan seperti keterampilan mengamati, mengajukan hipotesis, menggunakan alat dan bahan secara benar, menggolongkan, dan menafsirkan. Keterampilan-keterampilan tersebut mengarah pada keterampilan proses yang didalamnya secara tidak langsung melatih siswa untuk mengembangkan keterampilan berpikir kritis dan memupuk sikap kerjasama.

Sebagaimana yang tertulis pada tujuan pendidikan nasional, untuk membentuk manusia yang kreatif, dapat dilakukan untuk melatih keterampilan siswa dulu, dalam hal ini keterampilan berpikir kritisnya, oleh karena itu merencanakan pembelajaran biologi yang mengembangkan berpikir kritis merupakan suatu keharusan. Kemampuan berpikir siswa harus dikembangkan melalui pembelajaran yang dialami, karena kemampuan ini hanya akan berkembang apabila memang dikembangkan dan dilaksanakan dalam kegiatan pembelajaran.

Kenyataan di lapangan menunjukkan proses pembelajaran biologi masih berfokus pada penguasaan materi biologi setinggi-tingginya oleh siswa. Sedangkan penguasaan sikap dan keterampilan belum mendapat perhatian yang memadai. Penelitian Suratsih (2010:3) menyatakan bahwa pembelajaran biologi di sekolah masih didominasi dengan metode ceramah, interaksi antara subyek belajar dengan obyek belajar masih minim, sehingga proses mental dan psikomotorik belum optimal. Dampak dari hal tersebut adalah kurangnya penguasaan keterampilan kerja ilmiah yang seharusnya dimiliki siswa dalam belajar biologi.

Hasil survei peneliti di SMA Negeri 1 Batu Engau diperoleh data adanya beberapa hal yang menyebabkan siswa kurang terlatih atau kurang terampil untuk berpikir kritis, yaitu (1) kemampuan siswa untuk bertanya sangat rendah, karena ketidaktahuan atau apa 
yang ditanyakan, dan cara bertanya (ketrampilan bertanya kurang), (2) kemampuan kerja sama siswa kurang, terbatas pada menyelesaikan tugas secara insidental, (3) perangkat pembelajaran yang dipakai belum melatihkan keterampilan berpikir kritis, (4) kemampuan guru dalam menentukan strategi yang cocok dan bervariasi masih kurang, (5) ada anggapan dikalangan siswa dan guru bahwa orang yang bertanya adalah orang yang tidak mampu, bukan orang yang kritis, (6) pengetahuan masyarakat tentang pendidikan belum membudaya, dan menganggap pendidikan bukan hal yang penting, (7) adanya anggapan yang penting sekolah dan mendapat ijasah (tidak memerlukan kualitas), sehingga keinginan belajar kurang (motivasi orang tua kurang).

Keterampilan berpikir kritis dan kerjasama siswa ini diperlukan dalam upaya untuk mempersiapkan masa depan diri siswa dalam memecahkan masalah, termasuk dalam mengambil keputusan dalam dunia kerja yang akan dihadapi siswa kelak maupun dalam permasalahan sehari-hari. Keterampilan ini perlu dilatihkan oleh guru kepada siswa dalam kegiatan pembelajaran mereka di kelas. Pembelajaran biologi dengan metode yang tepat, diharapkan menjadi sarana pengembangan kemampuan berpikir ini, sehingga proses pembelajaran berlangsung optimal. Proses pembelajaran yang terencana dengan baik, sangat penting peranannya dalam pencapaian tujuan pendidikan.

Pencapaian tujuan tersebut memerlukan strategi pembelajaran yang tepat, yaitu metode pembelajaran yang mampu menggiatkan siswa untuk berpikir secara aktif dan kreatif di dalam proses pembelajaran, salah satunya adalah metode pembelajaran inkuiri. Arends (2012:342) menyatakan bahwa pembelajaran inkuiri dapat memberikan hasil, yaitu: meningkatkan pengetahuan penyelidikan, mengembangkan keterampilan berpikir penalaran, mengembangkan keterampilan metakognitif, dan mengembangkan sikap untuk melakukan penyelidikan.

Pencapaian tujuan tersebut memerlukan strategi pembelajaran yang tepat, yaitu metode pembelajaran yang mampu menggiatkan siswa untuk berpikir secara aktif dan kreatif di dalam proses pembelajaran, salah satunya adalah metode pembelajaran inkuiri. Arends (2012:342) menyatakan bahwa pembelajaran inkuiri dapat memberikan hasil, yaitu: meningkatkan pengetahuan penyelidikan, mengembangkan keterampilan berpikir penalaran, mengembangkan keterampilan metakognitif, dan mengembangkan sikap untuk melakukan penyelidikan.

Inkuiri merupakan salah satu pendekatan yang efektif dalam membantu siswa mengembangkan kemampuan berpikir yang lebih tinggi (Eggen dan Kauchak, 2012:234). Pendapat ini menjelaskan bahwa inkuiri dapat menjadikan seseorang pada level berpikir yang lebih tinggi dan siswa menjadi berminat dan terlibat dalam berbagai kegiatan.

Kardi (2013b:23) menjelaskan bahwa dalam pembelajaran inkuiri, guru berperan sebagai fasilitator dan bukan sebagai pemberi informasi pada pembelajaran inkuiri. Guru dapat menjawab secara langsung pertanyaan-pertanyaan yang muncul, tetapi tidak demikian halnya. Pertanyaan tersebut perlu dijawab sendiri oleh siswa, dengan bimbingan guru, melalui pengumpulan data hasil pengamatan, eksperimen, telaah pustaka, wawancara dan lainlainnya. Aktivitas-aktivitas tersebut menunjukkan keterlibatan siswa dalam pembelajaran. Melibatkan siswa di dalam kegiatan inkuiri merupakan salah satu cara efektif untuk membantu siswa mengembangkan keterampilan berpikir tingkat tinggi dan berpikir kritis. Hal ini sesuai dengan tujuan digunakannya model inkuiri, yaitu pengembangan keterampilan berpikir tingkat tinggi dan berpikir kritis.

Suchman (dalam Arends, 2012:342), menyatakan bahwa model pembelajaran inkuiri akan lebih memicu keingintahuan siswa tentang proses penyelidikannya dan belajar prosedur ilmiah secara langsung. Kardi (2013b:23) juga menyatakan bahwa model umum inkuiri adalah strategi mengajar yang dirancang untuk membimbing siswa bagaimana meneliti masalah dan pertanyaan berdasarkan fakta. Keterlibatan siswa di dalam kegiatan inkuiri merupakan salah satu cara yang efektif untuk membantu mereka mengembangkan keterampilan berpikir tingkat tinggi dan berpikir kritis.

Pembelajaran inkuiri dapat di integrasikan ke dalam beberapa model pembelajaran, karena ada fakta, konsep dan generalisasi, yang dapat melatih siswa untuk mengembangkan berpikir kritis. Menurut Kardi (2013b: 24-26) kebanyakan pembelajaran inkuiri memerlukan waktu lebih dari satu pertemuan, diperlukan perencanaan yang matang, disiplin dalam pelaksanaan, serta menyiasati dengan strategi yang lain (misal, pemberian tugas dalam kelompok), oleh karenanya guru perlu mempertimbangkan hal ini dalam merencanakan kegiatan inkuiri.

Gulo (2002) menyatakan bahwa pembelajaran inkuiri, di samping mengantarkan siswa pada tujuan instruksional tinggi, juga memberikan tujuan iringan yang menitikberatkan pada perkembangan kepribadian dan intelegensi siswa. Tujuan tersebut adalah (1) memperoleh keterampilan untuk memproses secara ilmiah (mengamati, mengumpulkan, dan menguji hipotesis, serta mengambil keputusan), (2) lebih berkembangnya daya kreativitas anak, (3) belajar secara mandiri, (4) lebih memahami hal-hal yang mendua, (5) perolehan sikap ilmiah terhadap ilmu pengetahuan yang menerimanya secara tentatif.

Menurut Arends (2012) pembelajaran inkuiri dikembangkan untuk mencapai 3 tujuan pembelajaran, 
yaitu:

a. Untuk membantu mengembangkan keterampilan intelektual siswa yang meliputi bertanya dan mencari jawaban

b. Membantu siswa mempelajari keterampilan proses inkuiri yang dihubungkan dengan berbagai aspek pembelajaran

c. Membantu siswa untuk mandiri dan mampu belajar sendiri

Penjelasan tersebut memberikan gambaran bahwa, inkuiri merupakan salah satu pendekatan yang dapat melibatkan siswa secara aktif dalam kegiatan pembelajaran, melalui serangkaian kegiatan ilmiah yang dpat melatih keterampilan berpikir kritis dan membangun kemampuan kerjasama diantara siswa.

Berdasarkan uraian yang telah dipaparkan sebelumnya, masalah dalam penelitian ini adalah "Bagaimanakah kelayakan perangkat pembelajaran berbasis inkuiri yang dikembangkan untuk melatih keterampilan berpikir kritis dan kerjasama siswa SMA pada pokok bahasan sistem eksresi manusia?".

\section{METODE PENELITIAN}

Penelitian ini tergolong jenis penelitian pengembangan, karena dalam penelitian ini akan dikembangkan perangkat pembelajaran biologi berbasis inkuiri pada sistem ekskresi.

Subjek penelitian ini adalah perangkat pembelajaran biologi berbasis inkuiri materi sistem ekskresi manusia. Uji coba dilakukan di SMA Negeri 1 Batu Engau kelas XI 2014/2015. Untuk uji coba 2 menggunakan 26 orang siswa SMA Negeri 1 Batu Engau Paser yang mengikuti pembelajaran biologi bahan kajian Sistem Ekskresi Manusia.

Penelitian dilaksanakan pada bulan oktober semester ganjil tahun pembelajaran 2014/2015. Implementasi perangkat pembelajaran pada penelitian ini dilakukan 3 kali pertemuan untuk tatap muka untuk pembelajaran dan 2 kali tatap muka untuk pretest dan posttest. Satu kali tatap muka 2 x 45 menit.

Penelitian ini merupakan penelitian pengembangan, yaitu pengembangan perangkat pembelajaran, yang terdiri dari 2 tahap, yaitu tahap perancangan perangkat pembelajaran dan tahap uji coba perangkat. Model pengembangan perangkat yang digunakan dalam penelitian ini adalah model Dick and Carey sesuai dengan kebutuhan pengembangan.

Rancangan penelitian ini menggunakan "One Group Pre Test-Post Test Design". Penelitian ini tergolong penelitian pengembangan. Rancangan ini dilakukan pada satu kelas saja tanpa menggunakan kelompok pembanding, dengan menggunakan rumus sebagai berikut:

$$
\begin{array}{lll}
\mathrm{O}_{1} & \mathrm{X} & \mathrm{O}_{2}
\end{array}
$$

Keterangan :

$$
\begin{aligned}
& \mathrm{O}_{1}=\text { uji awal, yaitu untuk mengetahui } \\
& \text { penguasaan materi ajar sebelum perlakuan } \\
& \mathrm{X}=\text { perlakuan, yaitu menerapkan KBM dengan } \\
& \text { bahan ajar yang dikembangkan } \\
& \mathrm{O}_{2}=\text { uji akhir, yaitu untuk mengetahui } \\
& \text { penguasaan materi ajar sesudah perlakuan }
\end{aligned}
$$

Pengumpulan data dalam penelitian ini dilakukan melalui pengamatan (observasi), penyebaran angket, dan pemberian tes. Teknik pengumpulan data yang digunakan dapat dijelaskan sebagai berikut.

\section{A. Observasi}

Observasi (pengamatan) bertujuan untuk mengumpulkan data penelitian tentang keterlaksanaan pembelajaran, aktivitas siswa, serta kendala-kendala atau hambatan-hambatan yang terjadi selama proses kegiatan belajar mengajar. Pengamatan dilakukan pada dua orang pengamat selama KBM, dengan menggunakan lembar pengamatan yang telah dikembangkan oleh peneliti.

\section{B. Angket}

Angket digunakan untuk mengetahui respon siswa terhadap penerapan pembelajaran yang dikembangkan peneliti melalui pendekatan inkuiri.

\section{Pemberian tes}

Tes diberikan untuk mengukur hasil belajar pengetahuan dan keterampilan berpikir kritis. Soal tes berupa 20 soal pilihan ganda dan 10 soal bentuk essay (uraian).

Data hasil pretest dan posttest kemampuan berpikir kritis dilakukan analisis deskriptif kualitatif menggunakan N-Gain. Gain menunjukkan perbedaan penguasaan atau pemahaman konsep siswa sebelum dan setelah diberikan perlakuan. Gain skor ternormalisasi menunjukkan tingkat efektivitas perlakuan daripada perolehan skor atau posttest. N-gain dirumuskan oleh Hake (1999:1) sebagai berikut:

$$
\%<\mathrm{g}>=\left(\%<\mathrm{S}_{\mathrm{f}}-\mathrm{S}_{\mathrm{i}}\right) /\left(100-\%<\mathrm{S}_{\mathrm{i}}>\right)
$$

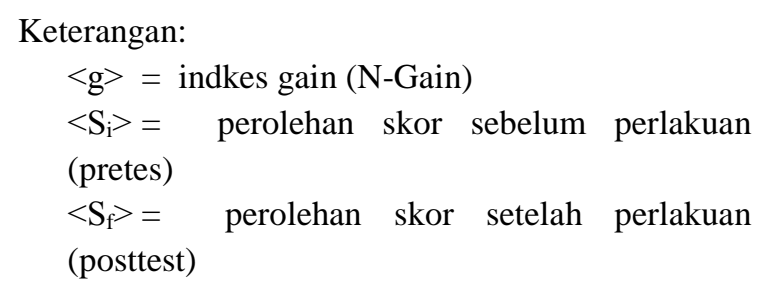

Kriteria N-Gain menurut Hake (1999) terbagi atas tiga tingkatan, yaitu: (1) pembelajaran dengan "gain tinggi", jika $<\mathrm{g}>\geq 0,7$; (2) pembelajaran dengan "gain sedang", jika $0,7><\mathrm{g}>\geq 0,3$; dan (3) pembelajaran dengan 'gain rendah", jika $<\mathrm{g}>, 0,3$. Pada penelitian ini 
nilai $\langle$ g $>$ sekurang-kurangnya $\geq 0,3$.

Kemampuan kerjasama siswa selama berlangsungnya kegiatan pembelajaran dihitung dengan rumus:

$$
\frac{\text { Skor yang diperoleh }}{\text { Skor maksimal }} \times 4=\text { Skor akhir }
$$
berikut:

Kemudian dikonversikan dengan kriteria sebagai

$$
\begin{array}{ll}
\text { Sangat baik }(\mathrm{SB}) & \text { : apabila } 3,33<\text { skor } \leq 4 \\
\text { Kurang baik }(\mathrm{KB}) & : \text { apabila } 2,33<\text { skor } \leq 3,33 \\
\text { Cukup }(\mathrm{C}) & : \text { apabila } 1,33<\text { skor } \leq 2,33 \\
\text { Kurang }(\mathrm{K}) & : \text { apabila }<1,33
\end{array}
$$

Persentase kemampuan kerjasama dianalisis dengan cara menghitung persentase aspek yang muncul pada setiap pertemuan. Persentase setiap aspek pada setiap pertemuan adalah jumlah frekuensi setiap aspek pengamatan dibagi dengan jumlah frekuensi semua aspek aktivitas dikali $100 \%$. Berdasarkan persentase tersebut diketahui aspek kemampuan tertinggi dan terendah. Teknik analisa data dapat digunakan dengan rumus berikut:

$$
\mathrm{P}=\frac{\sum \mathrm{R}}{\sum \mathrm{N}} \times 100 \%
$$

Keterangan:

$$
\begin{aligned}
\mathrm{P} \quad= & \text { persentase kemampuan kerjasama } \\
\sum \mathrm{R} & =\text { Jumlah frekuensi kategori pengamatan } \\
\sum \mathrm{N} & =\begin{array}{l}
\text { Jumlah frekuensi seluruh kategori } \\
\text { pengamatan }
\end{array}
\end{aligned}
$$

(Arifin, 2010:272)

Reliabilitas instrument pengamatan dihitung menggunakan rumus Percentage of Agreement dari Borich (1994:385) sebagai berikut:

$$
\mathrm{R}=\left[1-\frac{\mathrm{A}-\mathrm{B}}{\mathrm{A}+\mathrm{B}} \times 100\right] \%
$$

Keterangan:

$\mathrm{R}=$ Reliabilitas instrument pengamatan.

$\mathrm{A}=$ Frekuensi aspek tingkah laku yang teramati oleh pengamat yang memberikan frekuensi tinggi.

$\mathrm{B}=$ Frekuensi aspek tingkah laku yang teramati oleh pengamat yang memberikan frekuensi rendah.

\section{HASIL PENELITIAN DAN DISKUSI}

Penilaian berpikir kritis meliputi, kemampuan memberikan argument, memberikan prediksi, menganalisis, membuat kesimpulan, dan mengambil keputusan dan tindakan. Keterampilan berpikir kritis dilihat dari hasil tes dalam bentuk essay. Hasil penilaian uji berpikir kritis dapat dilihatpada persentase ketuntatasan indikator berpikir kritis, yang disajikan pada tabel 1 berikut.
Tabel 1. Persentase Ketuntasan Indikator Berpikir Kritis (\%)

\begin{tabular}{|c|l|c|c|}
\hline No & \multicolumn{1}{|c|}{ Indikator } & Pre Test & $\begin{array}{c}\text { Post } \\
\text { Test }\end{array}$ \\
\cline { 3 - 4 } & & Tuntas & Tuntas \\
\hline 1 & $\begin{array}{l}\text { Memberikan } \\
\text { argument }\end{array}$ & 30,8 & 96,2 \\
\hline 2 & Memprediksi & 3,8 & 96,2 \\
\hline 3 & Menganalisis & 23,1 & 96,2 \\
\hline 4 & Menyimpulkan & 23,1 & 96,2 \\
\hline 5 & $\begin{array}{l}\text { Mengambil keputusan } \\
\text { dan tindakan }\end{array}$ & 26,9 & 88,1 \\
\hline & Rata-rata & 21,5 & 94,6 \\
\hline
\end{tabular}

Berdasarkan tabel 1 dapat dilihat hasil ketuntasan untuk tes berpikir kritis pada saat pre test pada masingmasing indikator tidak lebih dari $30,8 \%$ atau rata-rata ketuntasannya $21,5 \%$, sedangkan untuk post testnya secara keseluruhan $\geq 70 \%$ atau rata-rata meningkat menjadi $94,6 \%$. Indikator berpikir kritis tertinggi adalah memberikan argument 96,2 \%, dan mengambil keputusan atau tindakan sebesar $88,1 \%$. Data tabel 1 memperlihatkan bahwa dari 5 indikator keterampilan berpikir kritis, semua telah mencapai ketuntasan.

Analisis tes kemampuan berpikir kritis ini menggunakan N-Gain dari Hake (1999:1). Berdasarkan hasil analisis diperoleh $\langle\mathrm{g}\rangle$ rata-rata sebesar 0,7 , dengan kriteria pembelajaran dengan "gain tinggi". Gain skor ini menunjukkan perbedaan penguasaan atau pemahaman konsep siswa sebelum dan setelah diberi perlakuan. Rangkuman normalized gain keterampilan berpikir kritis setiap indikator dapat dilihat pada grafik 1 berikut.

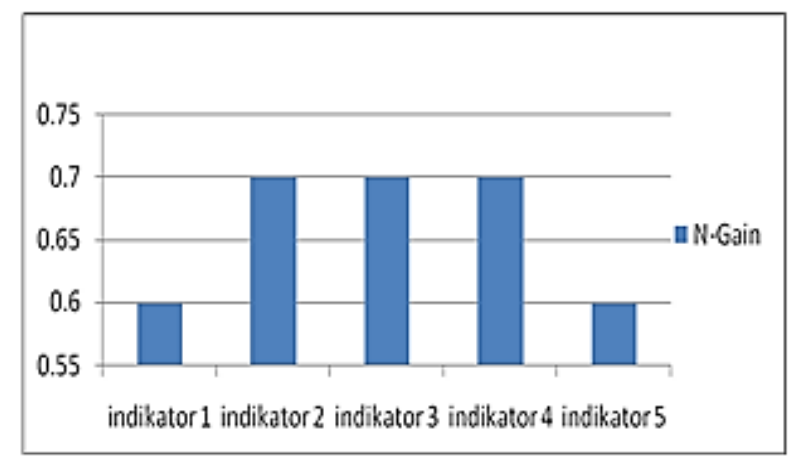

Grafik 1. Rangkuman N-Gain hasil Belajar Keterampilan Berpikir Kritis Setiap Indikator

Data pada grafik 1 menunjukkan bahwa semua indikator berpikir kritis memiliki normalized gain ratarata 0,7, yaitu pada kategori tinggi yang berarti ada perbedaan penguasaan siswa sebelum dan setelah diberi perlakuan, kriteria tersebut juga menunjukkan perlakuan yang diberikan cukup efektif. Data tersebut juga mengindikasikan bahwa perangkat pembelajaran menggunakan pendekatan inkuiri efektif melatih keterampilan berpikir siswa sebelum dan sesudah pembelajaran. Peningkatan tersebut terjadi karena dalam 
pembelajaran dengan menggunakan pendekatan inkuiri yang dilakukan secara kooperatif dapat memotivasi dan memfasilitasi siswa untuk melatih keterampilan berpikir kritis.

Menurut Kardi (2013b:32) melibatkan siswa didalam kegiatan inkuiri merupakan salah satu yang efektif untuk membantu siswa mengembangkan keterampilan berpikir tingkat tinggi dan berpikir kritis.

Borich (2006:29) menyatakan bahwa pembelajaran berbasis inkuiri adalah jenis pembelajaran dicapai melalui proses mencari informasi, pengetahuan dan kebenaran dengan mempertanyakan. Pembelajaran ini dapat digunakan dalam setiap disiplin, dan dapat dimasukkan ke dalam format yang berbeda untuk memecahkan masalah otentik dan menantang menggunakan kombinasi ceramah / presentasi, belajar mandiri, kelompok kecil kegiatan kolaboratif praktikum dan diskusi kelompok besar. Trautmann (2000) juga menyatakan bahwa pembelajaran inkuiri yang dilaksanakan secara berkelompok akan meningkatkan aktivitas belajar dan kemampuan berpikir kritis.

Hasil penelitian ini juga didukung oleh penelitianpenelitian yang terangkum dalam National Research Council (2000) yang memberikan hasil bahwa pengajaran berbasis inkuiri meningkatkan kemampuan berpikir kritis. Penelitian Hanifah (2013) juga menunjukkan bahwa pembelajaran menggunakan strategi inkuiri terbimbing dapat meningkatkan hasil belajar dan kemampuan berpikir kritis siswa.

Penilaian kemampuan kerjasama siswa, meliputi kemampuan membagi tugas, menyelesaikan tugas secara bersama, saling membantu, terbuka dan jujur terhadap semua anggota, dan menghargai pendapat anggota kelompok. Persentase kemampuan kerjasama dapat dilihat pada tabel 2 .

Tabel 2. Persentase Kemampuan Kerjasama Siswa (\%)

\begin{tabular}{|l|l|c|c|c|c|}
\hline No & \multicolumn{1}{|c|}{$\begin{array}{c}\text { Aspek yang } \\
\text { diamati }\end{array}$} & P ke-1 & P ke-2 & P ke-3 & $\begin{array}{c}\text { Rata- } \\
\text { rata }\end{array}$ \\
\hline 1 & $\begin{array}{l}\text { kemampuan } \\
\text { membagi tugas }\end{array}$ & 76 & 77 & 81 & 78 \\
\hline 2 & $\begin{array}{l}\text { menyelesaikan } \\
\text { tugas secara } \\
\text { bersama }\end{array}$ & 79 & 81 & 87 & 82,3 \\
\hline 3 & $\begin{array}{l}\text { saling } \\
\text { membantu }\end{array}$ & 78 & 80 & 83 & 80,3 \\
\hline 4 & $\begin{array}{l}\text { terbuka dan } \\
\text { jujur terhadap } \\
\text { semua anggota } \\
\text { kelompok }\end{array}$ & 77 & 79 & 82 & 79,3 \\
\hline 5 & $\begin{array}{l}\text { Menghargai } \\
\text { pendapat } \\
\text { anggota } \\
\text { kelompok }\end{array}$ & 83 & 86 & 93 & 87,3 \\
\hline \multicolumn{2}{|l|}{ Rata-rata total } & $\mathbf{7 8 , 6}$ & $\mathbf{8 0 , 6}$ & $\mathbf{8 5 , 2}$ & $\mathbf{8 1 , 5}$ \\
\hline
\end{tabular}

Berdasarkan tabel 2. Persentase rata-rata keseluruhan aspek kerjasama adalah $81,46 \%$. Aspek kemampuan kerjasama tertinggi adalah menghargai pendapat anggota kelompok, yaitu $87,3 \%$. Berikutnya $82,3 \%$ untuk aspek menyelesaikan tugas bersama dan saling membantu $80,3 \%$.

Kerjasama siswa dapat terjadi melalui pengelompokkan, siswa dapat saling bertukar pendapat, saling membantu untuk memecahkan masalah, menghargai pendapat teman dan dapat memicu siswa untuk aktif dalam KBM. Ibrahim, dkk (2000:16) juga menyatakan siswa lebih memiliki kemungkinan menggunakan tingkat berpikir yang lebih tinggi selama dan setelah diskusi kelompok kooperatif daripada belajar secara individual atau kompetitif. Kegiatan kooperatif juga mengajarkan kepada siswa keterampilan kerjasama dan kolaborasi.

Menurut Ahern (1999:204) siswa yang terlibat secara aktif dalam kegiatan kelompok kooperatif dan pemecahan masalah akan mengalami peningkatan berpikir kritis. Smith (2000:4) menyatakan bahwa pembelajaran kelompok kooperatif mempunyai potensi besar untuk mendukung pembelajaran berbasis inkuiri. Kerjasama dalam kelompok kooperatif ini lebih dari sekedar kedekatan fisik siswa dengan siswa lain, mendiskusikan materi dengan siswa lain, membantu siswa lain, atau bertukar pendapat antar siswa, semuanya merupakan bagian penting dalam pembelajaran kooperatif. Keterlibatan siswa, dorongan guru, dan interaksi siswa-siswa secara positif berhubungan dengan peningkatan berpikir kritis.

Teori perkembangan sosial menyatakan bahwa siswa lebih mampu belajar melalui interaksi dengan orang dewasa atau teman sebaya yang lebih mampu (Slavin, 2006:244). Siswa yang belajar dalam kelompoknya memungkinkan untuk terjadinya interaksi satu siswa dengan yang lain untuk lebih aktif dalam kegiatan pembelajaran. Ahern (1999:204) menyatakan bahwa belajar dalam kelompok kooperatif menekankan siswa untuk berinteraksi dengan yang lain. Interaksi siswa dengan yang lain memungkinkan siswa untuk terlibat aktif dalam kegiatan pembelajaran.

Hasil penelitian ini menunjukkan bahwa melalui pembelajaran dengan menggunakan perangkat pembelajaran berbasis inkuri selain dapat melatih keterampilan berpikir kritis juga dapat melatih kemampuan kerjasama siswa.

Temuan-temuan yang diperoleh dalam penelitian ini adalah keterampilan berpikir kritis siswa mengalami peningkatan yang terlihat dari ketuntasana indikator berpikir kritis mencapai 94,6\%. Kemampuan kerjasama dalam kegiatan pembelajaran inkuri secara umum adalah baik dan kerjasama yang sangat menonjol secara berurutan adalah menghargai pendapat anggota kelompok (87,3\%), dan saling membantu $(80,3 \%)$, 
menyelesaikan tugas bersama $(82,3 \%)$, terbuka dan jujur terhadap semua anggota $(79,3 \%)$, dan kemampuan membagi tugas $(78 \%)$.

Hambatan-hambatan yang ditemukan dalam penelitian ini adalah perlunya kesabaran dan ketelatenan guru dalam membimbing siswa, sehingga diperlukan pengaturan waktu yang terencana dengan baik.

\section{KESIMPULAN}

\section{A. Simpulan}

Berdasarkan temuan-temuan penelitian dapat dibuat simpulan bahwa pengembangan perangkat pembelajaran biologi berbasis inkuiri dapat melatih keterampilan berpikir kritis dan kerjasama siswa SMA yang dpat dilihat dari ketuntatasan indikator berpikir kritis $94,6 \%$. Kemampuan kerjasama siswa yang menonjol menghargai pendapat anggota kerjasama yang sangat menonjol secara berurutan adalah menghargai pendapat anggota kelompok $(87,3 \%)$.

\section{B. Saran}

Berdasarkan temuan-temuan penelitian disarankan, sebelum melakukan pembelajaran diluangkan waktu khusus untuk menjelaskan kepada siswa mengenai kegiatan pembelajaran yang akan dilakukan. Hal ini bertujuan siswa mempersiapkan diri, sehingga dapat mengikuti proses pembelajaran lebih baik.

\section{REFERENSI}

Ahern-Rindell, A.J. (1999). “Applying inquiry-based and cooperative group learning strategies to promote critical thinking". Journal of Collage Science Teaching (JCST). Vol. 28 No. 3, pp.203207.

Amin. (1997). Mengajarkan Ilmu Pengetahuan Alam (IPA) dengan menggunakan metode "Discovery" dan "Inquiry". Jakarta: Depdikbud.

Arends, R. I. (1997). Classroom instruction and management. USA: McGraw-Hill Companies.

Arends, R. I. (2012). Learning to teach. New York: McGraw Hill Companies, Inc.

Arifin, Z. (2009). Evaluasi pembelajaran. Bandung: Remaja Rosda Karya.

Astriani, D. (2006). Implementasi inkuiri dalam pembelajaran biologi dengan setting pembelajaran kooperatif di MAN Surabaya (Tesis magister pendidikan tidak dipublikasikan). Universitas Negeri Surabaya.

Campbell, N.A., Reece, J.B., and Mitchel, L.G. (2008). Biology 8th edition. San Francisco: Pearson Education Inc.

Baron, B., and Hammond, L. D. (2008). Teaching for meaningfull: Review of research on inquiry-based and cooperative learning. Amerika Serikat:
Stanford University.

Borich, G.D., and Ai-Choo Ong. (Eds). (2006). Teaching trategies that promote thinking: models and curriculum approaches. Singapore: McGrawHill Education (Asia).

Dananjaya, U. (2012). Media pembelajaran aktif. Bandung: Penerbit Nuansa.

Dewi, S. P. (2010). Studi perbandingan pembelajaran biologi metode kerja kelompok dan tanya jawab terhadap hasil belajar kognitif (Tesis magister pendidikan tidak dipublikasikan) Universitas Negeri Surabaya.

Dick, W., and Carey, L. (1990). The Systematic design of instrucion. United States of America: Harper Collins Publisher.

Eggen, P., and Kauchack, D. (2012). Strategy and models for teachers. Boston, London: Allyn and Balcon.

Ennis, R. H. (1996). Critical thinking. New Jersey: Prentice- Hall, Inc.

Fisher, A. (2007). Critical thinking: An Introduction. Amerika: Cambridge University Press.

Gulo, W. (2002). Strategi belajar mengajar. Jakarta: Gramedia Widia Sarana Indonesia.

Hanifah, A. 2013. Pengembangan perangkat pembelajaran materi pembelahan sel berbasis strategi inkuiri untuk melatih berfikir kritis siswa (Tesis magister pendidikan tidak dipublikasikan). Universitas Negeri Surabaya.

Hasan, S. (2014). "Inovasi pendidikan sains dalam menyongsong pelaksanaan kurikulum 2013". Makalah disajikan pada Seminar Nasional Program Studi Sains Pasca Sarjana UNESA, tanggal 18 Januari 2014.

Hasanah. (2008). Pengembangan perangkat pembelajaran biologi dengan model inkuiri di SMA nahdatul ulama 1 Gresik (Tesis magister pendidikan tidak dipublikasikan). Universitas Negeri Surabaya.

Ibrahim, M., Rachmadiarti, F., Nur, M., dan Isomono. (2000). Pembelajaran kooperatif. Surabaya: Universitas Negeri Surabaya University Press.

Ibrahim, M. (2005). Asesmen berkelanjutan: Konsep dasar, tahapan pengembangan dan contoh. Surabaya: UNESA University Press.

Ibrahim, M. (2012). Pembelajaran berdasarkan masalah. Surabaya: UNESA University Press.

Johnson, D., R. Johnson. and Edythe. J.H. (2004). Colaborative learning. Alexandria, Virginia: Interaction Book Company.

Johnson, M.D. (2008). Human biology. San Francisco: Pearson Education, Inc.

Joice, B., Weil, M. and Calhoun, E. ( 2009). Models of teaching. Boston: Allyn And Bacon.

Kardi, S. (2002). Mengembangkan tes hasil belajar. 
Surabaya: Universitas Negeri Surabaya.

Kardi, S. (2013a). Tujuan pembelajaran dan penggunaannya. Surabaya: Program Pasca Sarjana Universitas Negeri Surabaya.

Kardi, S. (2013b). Model pembelajaran langsung, inkuiri, sains teknologi dan masyarakat. Surabaya: Program Pasca Sarjana Universitas Negeri Surabaya.

Keller, J.M. (1987). "Development and use of the ARCS model of Instructional Design". Journal of Instructonal Development. Vol 3 No.10. pp.1-10

Kementrian Pendidikan dan Kebudayaan. (2013). Draf Kurikulum 2013. Jakarta: Kemendikbud.

Klionsky, J.D. (2001). "Constructing knowledge in the lecture hall". Journal of College Science Teaching. Vol. 31, pp. 246-251

Kurniasih, I.dan Berlin. (2014). Implementasi kurikulum 2013: konsep \& penerapan. Surabaya: Kata Pena.

McBridge, J. (2004). "Using an inquiry approach to teach science to secondary school science teacher". IOP Journal. pp. 1-6.

McGuire, M.J. (2007). "Why has the critical thinking movement not come to Korea?". Asia Pasific Education Review. Vol.8 No.2, pp.224-232.

Mulyasa. (2011). Menjadi guru profesional: Menciptakan pembelajaran kreatif dan menyenangkan. Bandung:PT Remaja Rosdakarya.

Mulyasa. (2013). Pengembangan dan implementasi kurikulum 2013. Bandung: PT. Remaja Rosda Karya.

National Research Council. (2000). Inquiry and the national science educational Standards. Washington,D.C: National Academy Press.

Nur, M. (2011). Modul keterampilan- keterampilan proses sains. Surabaya: Pusat Sains Dan Matematika Sekolah Universitas Negeri Surabaya.

Nur, M.dan Wikandari, P.R. (2000). Pengajaran berpusat pada siswa dan pendekatan konstruktivis dalam pengajaran. Surabaya: Pusat Studi Matematikan dan IPA Sekolah Universitas Negeri Surabaya.

Opara, A.J. (2011). "Inquiring method and student academic achievment in biology: Lesson and Policy Implication". American-Eurasian Journal of Scientific Research . Vol.6, No. 1, pp. 28-31.

Pandey, A.G. (2011). "Effectiveness of inquiry training model over conventional teaching method on academic achievment of science student in India". Journal of Innovative Research in Education. pp.7-20.

Peraturan Pemerintah No. 19 Tahun 2005 Tentang Standar Nasional Pendidikan (SNP).

Prastowo, A. (2012). Panduan kreatif membuat bahan ajar inovatif. Yogyakarta: DIVA Press.
Rustaman, N.Y. (2002). Pandangan biologi tentang proses berpikir dan implikasinya dalam pendidikan sains. Pidato Pengukuhan Jabatan Guru Besar Tetap dalam Pendidikan Biologi pada FPMIPA Universita Pendidikan Indonesia, tanggal 17 Oktober 2002.

Rustaman, N.Y. (2004). Peran pendidikan biologi di perguruan tinggi pada era globalisasi. Makalah Kunci disajikan Pada Seminar Nasional Pengembangan Pendidikan Biologi Menyongsong Era Globalisasi dan Pasar Bebas di Universitas Negeri Medan, Medan, 16 September 2004.

Rustaman, N.Y. (2007). Basic science inquiry in science education and its assesment. Makalah Utama dipresentasikan pada sidang pleno The First International Seminar of Education on "Science Education Facing against the challenges of the 21st Century" di Auditorium FPMIPA UPI Bandung.

Rustaman, N.Y. (2011). "Pendidikan dan penelitian sains dalam mengembangkan keterampilan berpikir tingkat tinggi untuk pembangunan karakter". Jurnal FKIP UNS. Vol 8 No.1. pp.4.

Sanjaya, W. (2006). Strategi pembelajaran berorientasi standar proses pendidikan. Jakarta: Kencana Prenada Media Group.

Slameto. (2010). Belajar dan faktor-faktor yang mempengaruhinya. Jakarta: Rineka Cipta.

Slavin, R.E. (2005). Cooperative learning: Theory, research and pracitce. London: Allymand Bacon.

Slavin, R.E. (2006). Educational psychology theory and practice. Boston: Pearson Education, Inc.

Smith, R.S. (2000). Inquiry-based cooperative learning. University of Minnesota/Purdue University.

Smith, R. S., Angelo, T., Matthews, H. and O'Steen, B. (2007). "How effective is inquiry-based learning in linking teaching and research?". Paper prepared for An International Colloquium on International Policies and Practices for Academic Enquiry. pp. 1-7.

Smith, R. S. (2007). "Experiencing the process of knowledge creation:The nature and use of inquirybased learning in higher education". Journal University of Otago, New Zealand. pp. 1-17.

Soewolo. (2000). Pengantar fisiologi hewan. Jakarta: Proyek Pengembangan Guru Sekolah Menengah IBRD Loan No. 3979 Direktorat Jenderal Pendidikan Tinggi Departemen Penddikan Nasional.

Subroto, H. (2001). "Upaya peningkatan profesionalisme guru melalui reward sistem". Media Pendidikan, Vol.24, No.6.

Suparmi, M. (2013). Pengembangan perangkat pembelajaran biologi berorientasi inkuiri untuk meningkatkan kemampuan berpikir kritis dan 
kemampuan kerjasama siswa (Tesis magister pendidikan tidak dipublikasikan). Universitas Negeri Surabaya.

Suratsih. (2010). Pengembangan modul pembelajaran biologi berbasis potensi lokal dalam kerangka implementasi KTSP SMA di Yogyakarta. Penelitian Unggulan UNY (Multitahun). Yogyakarta:Lembaga Penelitian UNY.

Suryanti. (2008). Model-model pembelajaran inovatif. Surabaya: Unesa University Press.
Trautman, N,M. (2000)." Integrated inquiry". Journal The Science Teacher. Vol.6 (67). pp:52-55.

Yulianti. (2011). Penerapan LKS inkuiri pada pembelajaran biologi untuk meningkatkan hasil belajar dan kemampuan berpikir siswa SMA. Surabaya: Tesis Pasca Sarjana UNESA.

Yusa, M. M. (2011). Advanced learning biology for grade XI B senior high school. Jakarta: Grafindo Pratama. 